\title{
Home appliances and gender gap of time spent on unpaid housework: evidence using household data from Vietnam
}

\author{
August 04, 2015 \\ Tien Manh $\mathrm{Vu}^{\dagger}$ \\ Japan Society for the Promotion of Science \\ Osaka University
}

[Keywords] Home appliances, Gender gap, Housework, Time use, Housework division [JEL Code] D13, J16, J22

[Abstract] We examined the gender gap between wives and husbands with regard to time spent on unpaid housework and the interaction terms between the appearance of home appliances and gender among 36,480 Vietnamese households. We found the gender gap of time is persistent regardless of the number of coresiding children, age cohorts, household size and income, and working status of the couples. Wives spent 40.3-58.6 minutes more on unpaid housework daily. In household fixed-effect estimations, we found the interaction terms had a positive relationship with the time spent on unpaid housework. Where a gas cooker was available, the time spent on unpaid housework of the wife was 16.9 minutes more than that of her husband on a daily basis. However, we did not detect any significant interaction effects among pure dual-wage earners, and where husbands are aged less than 26 years.

$\dagger$ Corresponding author: Tien Manh Vu

Osaka School of International Public Policy, Osaka University

1-31 Machikaneyama, Toyonaka, Osaka 560-0043, JAPAN.

Tel/Fax: +81-(0)6-6850-5656. E-mail: t-vu@osipp.osaka-u.ac.jp.

[Acknowledgments] I thank Hisakazu Matsushige of Osaka University and the participants of the International Association for Feminist Economics Annual Conference held in Berlin, Germany, in July 2015 for the valuable comments and suggestions. I acknowledge the financial support from the JSPS KAKENHI Grant number A26043110 from the Japanese Society for the Promotion of Science. 


\section{Introduction}

"Stoves were labor-saving devices but the labor that they saved was male."

Cowan (1983, page 61)

Our study examines whether the gender gap of time spent on unpaid housework exists and whether the appearance of home appliances reduces this gender gap between husbands and wives in Vietnam. We chose Vietnam because its transitioning economy contains both industrial and agricultural societies. Thanks to trade that is more open and to rising income levels, the lifestyle of Vietnamese households is improving ${ }^{1}$. In 2008, approximately $44.6 \%$, $11.9 \%$, and $31.1 \%$ of households owned a gas cooker, washing machine, and fridge, respectively ${ }^{2}$. However, this implies that the majority of households lived without these appliances. There has also been a shift from agricultural to nonagricultural work. For example, $55.1 \%$ of workers aged 15 years and over were employed in agriculture, forestry, and fishery in 2005 , but this number had fallen to $52.3 \%$ in $2008^{3}$. Therefore, the allocation of time spent on work, unpaid housework, and leisure has changed. In addition, the total fertility rate fell from 2.25 to 2.08 children during $2001-2008^{4}$. Thus, women had an increasing amount of time for paid work, leisure time, and unpaid housework over this period.

The majority of the literature in this area analyzes the negative relationship between time on paid work and unpaid housework among working couples. Hersch and Stratton (1997), Kimmel and Connelly (2008) and Bloemen (2010) are examples of such studies. Hersch (2009) finds that men substitute less paid work for unpaid housework than women do. Gronau (1977) shows that an increase in the wife's wage rate results in more paid working hours, less housework, and less leisure. Hersch and Stratton (1994) indicate that the gender gap on unpaid housework is due to the different wage rates of husbands and wives. Wales and Woodland (1997) further estimate the response of housework hours to the ratio of the wage rates. Gough (2011) finds unemployed individuals spend three to seven hours more per week on housework than when employed; and this increase is twice as large for women than for men. However, no study has investigated the case when both do not work, nor addressed the case where couples mix paid work with agricultural work and/or a home business.

\footnotetext{
${ }^{1}$ Vietnam joined the World Trade Organization in 2006 and experienced average annual GDP growth of over 5\% from 1990 to 2008 (http://www.gso.gov.vn/default_en.aspx?tabid=468\&idmid=3\&ItemID=12979).

${ }^{2}$ Authors' calculations.

${ }^{3}$ See http://www.gso.gov.vn/default_en.aspx?tabid=467\&idmid=3\&ItemID=12889.

${ }^{4}$ See http://www.gso.gov.vn/default_en.aspx?tabid=467\&idmid=3\&ItemID=12913.
} 
Although how husbands and wives allocate time on unpaid housework varies across countries, husbands tend to do less. Ueda (2005) shows that an hour of Japanese husbands' housework does not perfectly substitute for an hour of wives' housework. Bloemen et al. (2010) find that Italian husbands do less housework. Hersch and Stratton (1994) find that wives employed full time spend more time on both housework and paid work than their husbands do because women earn less. Hersch and Stratton (1994) find that if the gender wage gap declines, time spent on housework will be closer to equal. Folbre and Nelson (2000) find that if wives spend more time on paid work, husbands are less likely to increase time spent on unpaid housework to compensate. However, they did not consider the appearance of home appliances.

The explanations for the reallocation of time between husbands and wives vary and are not simple. Stratton (2012) indicates that men dislike housework. Thus, wives have to compensate. Kroska (2003) reports that women find baby care and laundry-related activities to be "good, potent, and active" and preparation of meals to be "particularly powerful," but dislike washing dishes more than men do. Poortman and Lippe (2009) show that women tend to favor cleaning, cooking, and childcare more than men do. Beblo and Robledo (2008) show that husbands have more leisure time because they are Stackelberg leaders in sequential private provision games. Analyzing French workweek reduction policy, Goux et al. (2014) find that husbands of policy-eligible woman tend to reduce their paid work time, while the wives show little response if their husband was in the target group of the policy.

In this study, we first investigate the time allocation between husbands and wives on unpaid housework and paid work using seemingly unrelated regressions. In the main analysis, we use household fixed-effect models to estimate the time gap on unpaid housework and then the interaction terms between the appearance of home appliances and gender. We find the gender gap of time is persistent and around 40.3-58.6 minutes per day, even among dualnonworking couples. We also find a positive nexus between the appearance of home appliances (gas cooker) and an increase in the time gap indicating less time on unpaid housework for men. We argue that the participation of the husband in specific unpaid housework tasks could be one of the main reasons for this nexus.

Our study extends the previous studies in several ways. To the best of our knowledge, this is the first empirical study analyzing the interaction between home appliances and the gender gap of time spent on unpaid housework. By eliminating the time-invariant factors in household fixed-effect models, we can measure the real "natural" gender gap between 
husbands and wives. Furthermore, we first consider the interaction terms for more than 26 types of household composition.

This paper proceeds as follows. The next section describes the data. Section 3 illustrates how we estimate the gender gap of time spent on housework using different samples. In Section 4 we present the results, and Section 5 presents the conclusions and discussion.

\section{Data}

We use the Vietnamese Household Living Standard Survey 2008 (VHLSS 2008). This provides cross-sectional and country-representative data from the General Statistics Office of Vietnam (GSO) using a two-stage stratified sampling method. The VHLSS 2008 design is identical to the Living Standards Measurement Studies by the World Bank. VHLSS 2008 is the latest survey containing information about housework from 45,945 households comprising 289,948 individuals. In the VHLSS, there are two questions: one about whether individuals do housework and if the answer is yes, the other concerns how many hours per day the individuals spent on housework on average during the previous 12 months. VHLSS 2008 defines housework as activities such as cleaning, shopping, cooking, washing clothes, fetching water and wood, and repairing tools. We refer to this definition as routine unpaid housework. The survey includes information about the availability of home appliances such as freezers, vacuum cleaners, washing machines and driers, gas cookers, rice cookers, and microwave ovens.

We use information on time spent on unpaid housework and the presence of home appliances as the main variables. We consider the head and the head's spouse as the husband and wife of the family in our analysis. After excluding households in which the head does not have a spouse, we have 36,480 households. The descriptive statistics of our data are presented in Tables 1 and 2.

[Insert Tables 1 and 2 here]

\section{Empirical methods}

We estimate two econometric models. The first are seemingly unrelated regressions (SURs) for the decisions of husbands and wives on time spent on paid work and unpaid housework. 
The second are household fixed-effect models (HHFEs) for analyzing the gender gap on time spent on unpaid housework.

We assume that both husband $j$ and wife $i$ in a household $k$ allocate their time simultaneously between paid work and unpaid housework in four reduced-form SURs as follows.

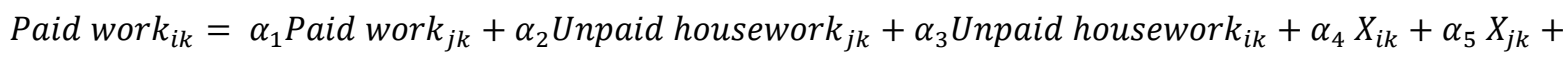
$\alpha_{6} D_{k}+\varepsilon_{i k}$

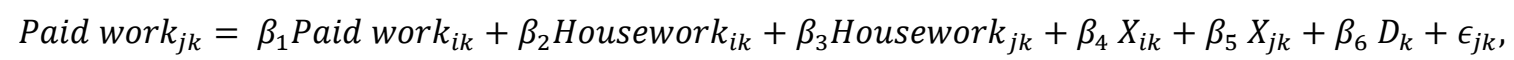

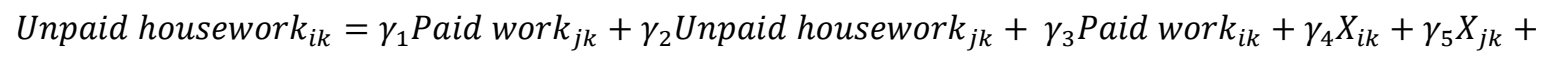
$\gamma_{6} D_{k}+\eta_{i k}$

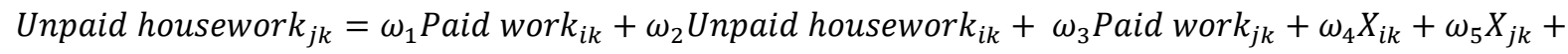
$\omega_{6} D_{k}+\theta_{j k}$

Each individual is required to consider his/her time spent on paid work and unpaid housework as well as that by their partner. The decision must be based on an individual's characteristics $\left(X_{i k}\right)$, their partner's characteristics $\left(X_{j k}\right)$ and those of the household $\left(D_{k}\right)$. Thus, $E\left(\varepsilon_{i k}, \epsilon_{j k}, \eta_{i k}, \theta_{j k} \mid X\right)=\sigma_{k}$ with a zero mean across households. Where the couples are not working, the SURs become two equations, (3) and (4).

We use HHFEs to analyze the gender gap in time spent on unpaid housework. For each household, we assume the time spent on unpaid housework depends mainly on (a) the variation that covariates with the gender of the individuals, (b) individuals' characteristics that vary between the husband and the wife $\left(X_{i k}\right)$, and (c) the preference or sharing rules or any factors that remain constant over time within the household (Household ${ }_{k}$ ).

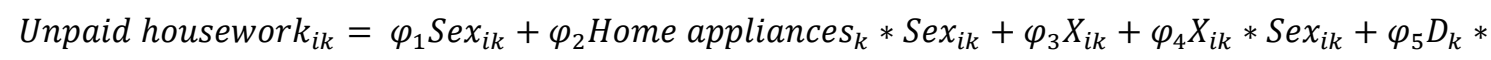
Sex $_{i k}+\varphi_{6}$ Household $_{k}+\vartheta_{i k}$

The time-invariant factors are captured by a dummy for each family. We use the Stata command areg in our analysis with 34,679 dummies (Household ${ }_{k}$ ). Thus, the coefficient $\varphi_{1}$ shows the "pure" gender gap in time spent on unpaid housework. Meanwhile, the interactions between the variables of interest with $S e x_{i k}$ show the marginal gap of time spent on housework between wife and husband if the variables of interest change by one unit, holding all other factors constant within the household. 
The main characteristics of individuals are described in Tables 1 and 2. Later labeled Absence-w/h (Ill day-w/h), "absence" ("ill day") indicates the total number of days in the 12 months prior to the survey that the wife/husband was absent (ill) and unable to do routine work. We construct four dummies for the number of coresiding children by age cohort from $0-6,7-12,13-17$, and for couples coresiding without any children.

We also add dummies for the appearance of home appliances in the household as well as construct the first principal component of the six appliances. We notice that pure dualwage earners are people who work for a salary, but who are not involved in any agricultural work for a family business. This is done to distinguish them from dual-wage earners who might do both of these types of work.

We divide the data into six main categories as a robustness check of the gender gap, and of the interaction between the variables of interest and gender. These categories are as follows. Working status (both not working, dual-working couples ${ }^{5}$, dual-wage earner, and pure dual-wage earner); number of coresiding children $(0,1,2,3,4$ and $>4)$; husband's age $(<26,26-35,36-45,46-55,56-65$, and $>65)$; quartiles of income (4 $4^{\text {th }}$ quartile is the richest $)^{6}$; household size $(<4,4,5$, and $>5)$; and dual-chore undertaken couples ${ }^{7}$. This is to separate the influence of these categories on the variables of interest and to provide an insight into any differences, if they exist. These categories help us to check the robustness of the results relative to the reduced forms equations of (5).

In addition, we apply three measures to deal with the high correlations between gas cookers and rice cookers ${ }^{8} /$ washing machines ${ }^{9} /$ freezers $(0.52,0.37$, and 0.43 , respectively). First, we conduct principal component analysis by constructing the first principal component $(P C A)$ from six interaction terms between gender and home appliance variables. Second, we retain gas cookers, vacuum cleaners, and microwave ovens in the analyses. Finally, we estimate separately each of the variables of interest for each of the data samples. We test their signs and statistical significance across the various data samples. We report the analyses with $P C A$ and three appliances as the main results, and present the other results in the Appendix.

\footnotetext{
${ }^{5}$ Dual-working couples are those who both do some work for income. Dual-wage earners are those that both do some jobs for wages.

${ }^{6}$ This is because the rich have more tools (Cowan 1983).

${ }^{7}$ Couples that spent at least one minute on unpaid housework.

${ }^{8}$ Unfortunately, the GSO uses the same code for rice cookers, electronic cookers, and pressure cookers. Therefore, we refer to this variable as "rice cookers" and use the coded variable to construct PCA for the six variables.

${ }^{9}$ The variable "washing machine" represents both washing machines and driers.
} 


\section{Results}

As shown in Table 4, the gender gap of time spent on unpaid housework is persistent and approximately 40.3 to 58.6 minutes per day. The gap is 18.24 minutes lower if both the husband and wife do unpaid housework for at least a minute each day. When comparing the gap across the data samples in Table 5, the gaps are statistically significant in 26 samples regardless of the working status, number of coresiding children, birth cohorts, income levels, and household sizes. This is consistent with the results of $\mathrm{Vu}$ (2014) who finds a daily 5.25minute gender gap between Vietnamese siblings aged less than 18 years on daily unpaid housework.

[Insert Tables 3, 4, and 5 here]

We find a substitution between paid work and unpaid housework in Table 3. The rate is different between men and women: 55 (43) minutes of paid work for one hour of unpaid housework for women (men). However, without any paid work, as seen in column (4) of Table 4, the gap is still 52 minutes each day.

Home appliances are associated with different amounts of time spent on housework between husbands and wives. For example, in Table 3, gas cookers help to reduce the time spent on unpaid housework for the husbands by much as 1.8 minutes per day. However, gas cookers increase the amount of unpaid housework of wives by 3.8 minutes per day.

The time gap between wives and husbands increases in association with the appearance of home appliances. As shown in column (1) of Table 4, the first principal component of the six home appliances increases the gap by 4.7 minutes per day for wives. We find the estimated $P C A$ is statistically insignificant among pure dual-wage earners, couples with more than four children, husbands aged less than 26 , and those in the lowest income quartile as shown in Table 5.

Examining the effects of specific appliances, we find the interaction term constructed from gas cookers and gender has the most statistically significant coefficient of 16.9 minutes per day as shown in column (2) of Table 4. The significance of the coefficients is independent of model specifications that include or exclude other home appliances as shown in the corresponding coefficients in both Table 5 and the Appendix. However, the coefficients become statistically insignificant for pure dual-wage earners where the husband is aged less than 26 years. Among the couples living with more than four children or in the lowest income 
quartile, the statistically insignificant $P C A$ could be due to the opposite signs of the interaction terms.

The decision to participate in unpaid housework is one of the main reasons for women spending more time on housework following the appearance of gas cookers. We find that with a gas cooker, husbands are $6 \%$ less likely to do unpaid housework, while the wife is only $0.6 \%$ less likely as shown in Table 6 . This might be because men believe that the cooking with a gas cooker is not difficult enough to warrant their help. Without a gas cooker, men may become involved in tasks such as collecting and chopping firewood.

\section{[Insert Table 6 here]}

We hypothesize some additional reasons for the increased gender gap in time associated with the appearance of home appliances, particularly gas cookers. First, it could be that men do less housework while women do more, as shown in columns (7) and (8) of Table 3. Second, although gas cookers reduce cooking time because of convenient heat adjustment and multiple-task heating, they allow women to cook more dishes per meal. Thus, the total time spent using gas cookers and cleaning dishes (we assume that women are more likely to do such cleaning) increases. Third, gas cookers might be more closely related to wives' tasks, whereas other home appliances could be gender-neutral. Washing machines, microwave ovens, and vacuum cleaners do not require a specific strength or skill related to feminine/masculine characteristics. Fourth, wives could be more involved because they consider cooking time as leisure time. Indirect evidence is that women who are pure dualwage earners are more likely to participate (a $1.25 \%$ increase) if the household owns a gas cooker (see Table 6).

Meanwhile, among pure dual-wage earners, we would argue that the time adjustment of the couples when all income comes from paid work would be rigid. Thus, time constraints give women no opportunity to increase time spent on unpaid housework even if it is considered a leisure activity. Furthermore, by having stable income, women can have more bargaining power. Thus, men cannot avoid collaborating with women and sharing tasks related to gas cookers. These arguments could explain why the time gap in the two groups is the same, and why women are more likely to do housework where a gas cooker is available. 


\section{Conclusions and discussion}

We examined the time spent on unpaid housework by 36,480 Vietnamese couples. The gender gap is persistent across generations despite changes in the Vietnamese economy. Despite differences in household composition in terms of age, size, income, number of coresiding children, and working status, we found that husbands spend 40.3-58.6 fewer minutes each day on unpaid housework than their wives do. One of the important reasons is that men are less likely to do housework. Working status can explain the substitution between paid work and unpaid housework. However, among dual-nonworking couples, the gender gap of time was still 52 minutes. We also found that some home appliances (such as microwave ovens and gas cookers) reduce the time spent on housework by husbands. Nevertheless, the gender gap of time increases with the appearance of home appliances such as gas cookers. We found that a reduction in the probability of men participating in housework tasks related to gas cookers is one of the main reasons for the larger gap. In addition, a woman may do more housework as a leisure activity and because a gas cooker enables her to cook more dishes and do other related tasks (such as cleaning). However, this effect does not exist among pure dualwage earners or in cases where husbands are aged less than 26 years.

We acknowledge several limitations of our data and analyses. First, the time spent on housework is retrospective, but not in a form of time use survey where each specific task of each individual is recorded with both the starting and the ending time. Second, we bypassed the self-selection of men and women toward specific tasks, the productivity of doing housework and the collaboration between couples on the same task. Thus, the gender gap might be associated with the specific tasks included in the survey. Third, we were only able to consider gas cookers, but not other types of cookers such as electronic cookers, pressure cookers, and rice cookers. This is because the survey coded the three mentioned cookers in the same variable.

The positive relationship between gender gap of time and the appearance of home appliances has several policy implications. First, the gap exists because individuals might be self-selected to certain specific tasks of unpaid housework. Thus, policies to increase the participation of women in paid work should consider this effect. Second, the positive interaction terms indicate that the policies facilitating the participation of men in housework also empower women. This can also influence the marketing strategies of the suppliers of home appliances. Similarly, policies aimed at empowering women via microcredit should 
consider this interaction. Finally, our study confirms the existence of gender roles in terms of unpaid housework between husbands and wives.

\section{References}

Beblo M, Robledo JR (2008) The wage gap and the leisure gap for double-earner couples. J Popul Econ 21(2):281-304. doi:10.1007/s00148-006-0132-5

Bloemen HG, Pasqua S, Stancanelli EGF (2010) An empirical analysis of the time allocation of Italian couples: are they responsive? Rev Econ Househ 8(3):345-369. doi:10.1007/s11150-009-9083-4

Connelly R, Kimmel J (2009) Spousal influences on parents' non-market time choices. Rev Econ Househ 7(4):361-394. doi:10.1007/s11150-009-9060-y

Cowan RS (1983) More work for mother. Basic Books, New York.

Folbre N, Nelson JA (2000) For love or money—or both? J Econ Perspect 14(4):123-140. doi:10.1257/jep.14.4.123

Gershuny J, Sullivan O (2014) Household structure and housework: Assessing the contributions of all household members, with a focus on children and youths. Rev Econ Househ 12(1):7-27. doi:10.1007/s11150-013-9234-5

Gough M (2011) Unemployment in families: The case of housework. J Ind Econ 59(3):10851100. doi:10.1111/j.1741-3737.2011.00867.x

Goux D, Maurin E, Petrongolo B (2014) Worktime regulations and spousal labor supply. Am Econ Rev 104(5639):252-276. doi:10.1257/aer.104.1.252

Gronau R (1977) Leisure, home production, and work - the theory of the allocation of time revisited. J Polit Econ 85(6):1099. doi:10.1086/260629

Hersch J (2009) Home production and wages: Evidence from the American Time Use Survey. Rev Econ Househ 7(2):159-178. doi:10.1007/s11150-009-9051-z

Hersch J, Stratton LS (1994) Housework, wages, and the division of housework time for employed spouses. Am Econ Rev 84(2):120-125.

Hersch J, Stratton LS (1997) Housework, fixed effects, and wages of married workers. J Hum Resour 32(2):285-307.

Kroska A (2003) Investigating gender differences in the meaning of household chores and child care. J Marriage Fam 65(2):456-473. doi:10.1111/j.1741-3737.2003.00456.x

Poortman AR, Van Der Lippe T (2009) Attitudes toward housework and child care and the gendered division of labor. J Marriage Fam 71(3):526-541. doi:10.1111/j.17413737.2009.00617.x 
Stratton LS (2012) The role of preferences and opportunity costs in determining the time allocated to housework. Am Econ Rev 102(3):606-611. doi:10.1257/aer.102.3.606

Ueda A (2005) Intrafamily time allocation of housework: Evidence from Japan. J Jpn Int Econ 19(1):1-23. doi:10.1016/j.jjie.2003.12.002

Vu TM (2014) Are daughters always the losers in the chore war? Evidence using household data from Vietnam. J Dev Stud 50(4):520-529. doi:10.1080/00220388.2013.875535

Wales TJ, Woodland, AD (1977) Estimation of the allocation of time for work, leisure, and housework. Econometrica 45(1):115-132. 
Table 1 Descriptive statistics of husbands and wives in the selected sample

\begin{tabular}{|c|c|c|c|c|c|c|c|c|}
\hline \multirow[b]{2}{*}{ Variables } & \multicolumn{4}{|l|}{ Wife } & \multicolumn{4}{|c|}{ Husband } \\
\hline & Mean & Std. dev. & Min. & Max. & Mean & Std. dev. & Min. & Max. \\
\hline UHW (daily hours of unpaid housework) & 2.354 & 1.238 & 0 & 8 & 1.149 & 0.994 & 0 & 8 \\
\hline PW (daily hours of paid work) & 3.815 & 2.619 & 0 & 17.753 & 4.013 & 2.508 & 0 & 16.767 \\
\hline UHW (daily hours of unpaid housework $>0, \mathrm{~N}=25,924$ ) & 2.380 & 1.096 & 1 & 8 & 1.560 & 0.808 & 1 & 8 \\
\hline PW (daily hours of paid work $>0, N=30,253$ ) & 4.364 & 2.310 & 0.011 & 16.767 & 4.428 & 2.200 & 0.016 & 16.767 \\
\hline Work for income $(1=$ yes, $0=$ no $)$ & 0.874 & 0.332 & 0 & 1 & 0.901 & 0.299 & 0 & 1 \\
\hline Dual-wage earners & 0.646 & 0.478 & 0 & 1 & 0.498 & 0.500 & 0 & 1 \\
\hline Pure dual-wage earners & 0.102 & 0.303 & 0 & 1 & 0.159 & 0.366 & 0 & 1 \\
\hline Age & 45.553 & 11.916 & 18 & 92 & 48.459 & 12.359 & 18 & 98 \\
\hline Years of schooling & 6.953 & 4.081 & 0 & 20 & 7.986 & 4.046 & 0 & 19 \\
\hline Absence (Absent days from routine tasks in previous 12 months) & 5.673 & 19.419 & 0 & 365 & 5.680 & 22.377 & 0 & 365 \\
\hline Ill days (Number of days in illness in previous 12 months) & 1.741 & 11.399 & 0 & 365 & 2.229 & 16.726 & 0 & 365 \\
\hline
\end{tabular}

Total number of households $=36,480$ 
Table 2 Descriptive statistics of households in the selected sample

\begin{tabular}{lllll}
\hline Variables $^{\mathrm{a}}$ & Mean & Std. dev. & Min. & Max. \\
\hline 0 children $^{\mathrm{a}}$ & 0.106 & 0.307 & 0 & 1 \\
1 child & 0.211 & 0.408 & 0 & 1 \\
2 children & 0.408 & 0.491 & 0 & 1 \\
3 children & 0.177 & 0.382 & 0 & 1 \\
4 children & 0.064 & 0.244 & 0 & 1 \\
More than 4 children & 0.099 & 0.299 & 0 & 1 \\
Number of children aged < 7 & 0.400 & 0.662 & 0 & 8 \\
Number of children aged 7-12 & 0.446 & 0.675 & 0 & 5 \\
Number of children aged 13-17 & 0.538 & 0.719 & 0 & 5 \\
Number of other adults (age > 18 \& excluding the head and the & & & & \\
head's spouse) & 3.041 & 1.190 & 2 & 10 \\
House living area in square meters & 69.470 & 40.386 & 5 & 1,056 \\
Tap water (being used) & 0.215 & 0.411 & 0 & 1 \\
Freezer & 0.311 & 0.463 & 0 & 1 \\
Washing machine & 0.119 & 0.323 & 0 & 1 \\
Gas cooker & 0.446 & 0.497 & 0 & 1 \\
Rice cooker & 0.693 & 0.461 & 0 & 1 \\
Vacuum cleaner & 0.012 & 0.109 & 0 & 1 \\
Microwave oven & 0.024 & 0.152 & 0 & 1 \\
Urban & 0.245 & 0.430 & 0 & 1 \\
\hline
\end{tabular}

${ }^{\mathrm{a}}$ Children are those of the head and are coresiding in the household. Total number of households $=36,480$ 
Table 3 Seemingly unrelated regressions with four decisions on time spent on paid work and unpaid housework

\begin{tabular}{|c|c|c|c|c|c|c|c|c|}
\hline \multirow{3}{*}{ Variables } & \multicolumn{4}{|c|}{$1^{\text {st }}$ PC of 6 appliances } & \multicolumn{4}{|c|}{ Three appliances } \\
\hline & PW-W & $\mathrm{PW}-\mathrm{h}$ & UHW-w & UHW-h & PW-W & $\mathrm{PW}-\mathrm{h}$ & UHW-w & UHW-h \\
\hline & $(1)$ & $(2)$ & (3) & $(4)$ & $(5)$ & $(6)$ & $(7)$ & $(8)$ \\
\hline PW-W & & $\begin{array}{l}0.601 \text { **** } \\
(0.004)\end{array}$ & $\begin{array}{l}-0.263^{* * *} \\
(0.003)\end{array}$ & $\begin{array}{l}0.144 * * * \\
(0.002)\end{array}$ & & $\begin{array}{l}0.601 \text { **** } \\
(0.004)\end{array}$ & $\begin{array}{l}-0.263 * * * \\
(0.003)\end{array}$ & $\begin{array}{l}0.144 * * * * \\
(0.002)\end{array}$ \\
\hline PW-h & $\begin{array}{l}0.681 * * * \\
(0.005)\end{array}$ & & $\begin{array}{l}0.191 * * * \\
(0.003)\end{array}$ & $\begin{array}{l}-0.158^{* * *} \\
(0.002)\end{array}$ & $\begin{array}{l}0.681 * * * \\
(0.005)\end{array}$ & & $\begin{array}{l}0.190 * * * \\
(0.003)\end{array}$ & $\begin{array}{l}-0.158 \text { *** } \\
(0.002)\end{array}$ \\
\hline UHW-w & $\begin{array}{l}-0.913 \text { *** } \\
(0.009)\end{array}$ & $\begin{array}{l}0.636^{* * * *} \\
(0.009)\end{array}$ & & $\begin{array}{l}0.246 * * * \\
(0.004)\end{array}$ & $\begin{array}{l}-0.913 * * * \\
(0.009)\end{array}$ & $\begin{array}{l}0.636 * * * \\
(0.009)\end{array}$ & & $\begin{array}{l}0.246 * * * \\
(0.004)\end{array}$ \\
\hline UHW-h & $\begin{array}{l}0.746^{* * * *} \\
(0.012)\end{array}$ & $\begin{array}{l}-0.721 * * * \\
(0.011)\end{array}$ & $\begin{array}{l}0.347 * * * \\
(0.006)\end{array}$ & & $\begin{array}{l}0.746^{* * * *} \\
(0.012)\end{array}$ & $\begin{array}{l}-0.721 \text { *** } \\
(0.011)\end{array}$ & $\begin{array}{l}0.347 * * * \\
(0.006)\end{array}$ & \\
\hline Absence-w & $\begin{array}{l}-0.010 * * * \\
(0.001)\end{array}$ & & $\begin{array}{l}-0.005^{* * *} \\
(0.000)\end{array}$ & $\begin{array}{l}0.003 * * * \\
(0.000)\end{array}$ & $\begin{array}{l}-0.010^{* * * *} \\
(0.001)\end{array}$ & & $\begin{array}{l}-0.005 * * * \\
(0.000)\end{array}$ & $\begin{array}{l}0.003 * * * \\
(0.000)\end{array}$ \\
\hline Ill day-w & $\begin{array}{l}-0.010^{* * * *} \\
(0.001)\end{array}$ & & $\begin{array}{l}-0.007 * * * \\
(0.001)\end{array}$ & $\begin{array}{l}0.005^{* * * *} \\
(0.000)\end{array}$ & $\begin{array}{l}-0.010^{* * * *} \\
(0.001)\end{array}$ & & $\begin{array}{l}-0.007 * * * \\
(0.001)\end{array}$ & $\begin{array}{l}0.005 * * * \\
(0.000)\end{array}$ \\
\hline Absence- $\mathrm{h}$ & & $\begin{array}{l}-0.010 * * * \\
(0.000)\end{array}$ & $\begin{array}{l}0.002 * * * \\
(0.000)\end{array}$ & $\begin{array}{l}-0.003^{* * *} \\
(0.000)\end{array}$ & & $\begin{array}{l}-0.010 * * * \\
(0.000)\end{array}$ & $\begin{array}{l}0.002 * * * \\
(0.000)\end{array}$ & $\begin{array}{l}-0.003 \text { *** } \\
(0.000)\end{array}$ \\
\hline Ill day-h & & $\begin{array}{l}-0.008 * * * \\
(0.001)\end{array}$ & $\begin{array}{l}0.003 * * * \\
(0.000)\end{array}$ & $\begin{array}{l}-0.004 * * * * \\
(0.000)\end{array}$ & & $\begin{array}{l}-0.008^{* * * *} \\
(0.001)\end{array}$ & $\begin{array}{l}0.003 * * * \\
(0.000)\end{array}$ & $\begin{array}{l}-0.004 * * * \\
(0.000)\end{array}$ \\
\hline Living without a child & & & $\begin{array}{l}0.023 \\
(0.023)\end{array}$ & $\begin{array}{l}0.088^{* * * *} \\
(0.020)\end{array}$ & & & $\begin{array}{l}0.022 \\
(0.023)\end{array}$ & $\begin{array}{l}0.089 * * * \\
(0.020)\end{array}$ \\
\hline Child $^{\text {a }}$ aged $<7$ & & & $\begin{array}{l}0.011 \\
(0.010)\end{array}$ & $\begin{array}{l}0.002 \\
(0.008)\end{array}$ & & & $\begin{array}{l}0.012 \\
(0.010)\end{array}$ & $\begin{array}{l}0.001 \\
(0.008)\end{array}$ \\
\hline Child aged 7-12 & & & $\begin{array}{l}-0.029 * * * \\
(0.009)\end{array}$ & $\begin{array}{l}-0.019^{* *} \\
(0.008)\end{array}$ & & & $\begin{array}{l}-0.028 * * * \\
(0.009)\end{array}$ & $\begin{array}{l}-0.019 * * \\
(0.008)\end{array}$ \\
\hline Child aged 13-17 & & & $\begin{array}{l}-0.070 * * * \\
(0.009)\end{array}$ & $\begin{array}{l}-0.074 * * * \\
(0.008)\end{array}$ & & & $\begin{array}{l}-0.069 * * * \\
(0.009)\end{array}$ & $\begin{array}{l}-0.074 * * * \\
(0.008)\end{array}$ \\
\hline Number of adults & & & $\begin{array}{l}-0.056^{* * * *} \\
(0.006)\end{array}$ & $\begin{array}{l}-0.073 * * * \\
(0.005)\end{array}$ & & & $\begin{array}{l}-0.056 \text { *** } \\
(0.006)\end{array}$ & $\begin{array}{l}-0.073 * * * \\
(0.005)\end{array}$ \\
\hline House living area & & & $\begin{array}{l}0.000 * * * \\
(0.000)\end{array}$ & $\begin{array}{l}-0.000 \\
(0.000)\end{array}$ & & & $\begin{array}{l}0.000 * * * \\
(0.000)\end{array}$ & $\begin{array}{l}-0.000^{*} \\
(0.000)\end{array}$ \\
\hline Tap water & & & $0.041^{* *}$ & $-0.045^{* * *}$ & & & $0.042 * *$ & $-0.047 * * *$ \\
\hline & & & $(0.018)$ & $(0.015)$ & & & $(0.018)$ & $(0.015)$ \\
\hline PCA (6 appliances) & & & $\begin{array}{l}0.015 * * * \\
(0.005)\end{array}$ & $\begin{array}{l}-0.014 * * * \\
(0.004)\end{array}$ & & & & \\
\hline Gas cooker & & & & & & & $\begin{array}{l}0.063 * * * \\
(0.014)\end{array}$ & $\begin{array}{l}-0.030 * * \\
(0.012)\end{array}$ \\
\hline Vacuum cleaner & & & & & & & $\begin{array}{l}0.002 \\
(0.055)\end{array}$ & $\begin{array}{l}-0.031 \\
(0.047)\end{array}$ \\
\hline Microwave oven & & & & & & & $\begin{array}{l}-0.006 \\
(0.041)\end{array}$ & $\begin{array}{l}-0.067^{*} \\
(0.035)\end{array}$ \\
\hline Age and age ${ }^{\wedge} 2$ & Yes & Yes & Yes & Yes & Yes & Yes & Yes & Yes \\
\hline Schooling years & Yes & Yes & & & Yes & Yes & & \\
\hline Provinces \& urban & & & Yes & Yes & & & Yes & Yes \\
\hline Constant & $\begin{array}{l}0.631 * * * \\
(0.144)\end{array}$ & $\begin{array}{l}1.403 * * * \\
(0.148)\end{array}$ & $\begin{array}{l}1.967 * * * \\
(0.090)\end{array}$ & $\begin{array}{l}0.632 * * * \\
(0.083)\end{array}$ & $\begin{array}{l}0.630 * * * \\
(0.144) \\
\end{array}$ & $\begin{array}{l}1.405^{* * *} \\
(0.148)\end{array}$ & $\begin{array}{l}1.943 * * * \\
(0.090)\end{array}$ & $\begin{array}{l}0.656 * * * \\
(0.083)\end{array}$ \\
\hline Observations & 36,480 & 36,480 & 36,480 & 36,480 & 36,480 & 36,480 & 36,480 & 36,480 \\
\hline $\mathrm{R}$-squared & 0.182 & 0.239 & 0.107 & 0.040 & 0.182 & 0.239 & 0.108 & 0.040 \\
\hline
\end{tabular}

Robust standard errors in parentheses $(* * * \mathrm{p}<0.01$, ** $\mathrm{p}<0.05, * \mathrm{p}<0.1)$. Children are those of the head and are coresiding in the household 
Table 4 Household fixed-effect models on time spent on unpaid housework

\begin{tabular}{|c|c|c|c|c|}
\hline \multirow{4}{*}{ Variables } & \multirow[t]{2}{*}{$\begin{array}{l}1^{\text {st }} \mathrm{PC} \text { from } 6 \\
\text { appliances }\end{array}$} & \multicolumn{3}{|l|}{$\begin{array}{l}\text { Three } \\
\text { appliances }\end{array}$} \\
\hline & & All & Both do chores & Both do not work \\
\hline & UHW & UHW & UHW & UHW \\
\hline & $(1)$ & $(2)$ & (3) & (4) \\
\hline Sex & $\begin{array}{l}0.952^{* * * *} \\
(0.029)\end{array}$ & $\begin{array}{l}0.976^{* * *} \\
(0.028)\end{array}$ & $\begin{array}{l}0.672 * * * \\
(0.026)\end{array}$ & $\begin{array}{l}0.863 * * * \\
(0.127)\end{array}$ \\
\hline PCA & $\begin{array}{l}0.078 * * * \\
(0.007)\end{array}$ & & & \\
\hline Gas cooker $\times$ sex & & $\begin{array}{l}0.281 * * * \\
(0.025)\end{array}$ & $\begin{array}{l}0.197 * * * \\
(0.023)\end{array}$ & $\begin{array}{l}0.439 * * * \\
(0.129)\end{array}$ \\
\hline Microwave oven $\times$ sex & & $\begin{array}{l}0.274 * * * \\
(0.103)\end{array}$ & $\begin{array}{l}0.299 * * * \\
(0.106)\end{array}$ & $\begin{array}{l}0.108 \\
(0.263)\end{array}$ \\
\hline Vacuum cleaner $\times$ sex & & $\begin{array}{l}0.004 \\
(0.119)\end{array}$ & $\begin{array}{l}0.114 \\
(0.121)\end{array}$ & $\begin{array}{c}-0.492 \\
(0.375)\end{array}$ \\
\hline Working hour & $\begin{array}{l}-0.116^{* * *} \\
(0.007)\end{array}$ & $\begin{array}{l}-0.115 * * * \\
(0.007)\end{array}$ & $\begin{array}{l}-0.080 * * * \\
(0.006)\end{array}$ & \\
\hline Absence & $\begin{array}{l}-0.006 * * * \\
(0.001)\end{array}$ & $\begin{array}{l}-0.006 * * * \\
(0.001)\end{array}$ & $\begin{array}{l}-0.002 * * * \\
(0.001)\end{array}$ & $\begin{array}{l}-0.006 * * * \\
(0.001)\end{array}$ \\
\hline Ill day & $\begin{array}{l}-0.008 * * * \\
(0.001)\end{array}$ & $\begin{array}{l}-0.008 * * * \\
(0.001)\end{array}$ & $\begin{array}{l}-0.004 * * \\
(0.002)\end{array}$ & $\begin{array}{l}-0.008 * * * \\
(0.001)\end{array}$ \\
\hline Dual-wage earners & $\begin{array}{l}-0.345 * * * \\
(0.031)\end{array}$ & $\begin{array}{l}-0.344 * * * \\
(0.031)\end{array}$ & $\begin{array}{l}-0.288 * * * \\
(0.029)\end{array}$ & \\
\hline Pure dual-wage earners & $\begin{array}{l}-0.380 * * * \\
(0.059)\end{array}$ & $\begin{array}{l}-0.382 * * * \\
(0.060)\end{array}$ & $\begin{array}{l}-0.206 * * * \\
(0.061)\end{array}$ & \\
\hline Age and age $\wedge^{\wedge} 2$ & Yes & Yes & Yes & Yes \\
\hline Head of the household & Yes & Yes & Yes & Yes \\
\hline Self-employed (types 1-3) & Yes & Yes & Yes & \\
\hline Working (dummy) & Yes & Yes & Yes & \\
\hline N/2-1 dummies of households & Yes & Yes & Yes & Yes \\
\hline Constant & $\begin{array}{l}2.001 * * * \\
(0.299)\end{array}$ & $\begin{array}{l}1.954 * * * \\
(0.299) \\
\end{array}$ & $\begin{array}{l}2.869 * * * \\
(0.317) \\
\end{array}$ & $\begin{array}{l}12.396 * * * \\
(3.771)\end{array}$ \\
\hline Observations $(\mathrm{N})$ & 72,960 & 72,960 & 51,848 & 3,972 \\
\hline $\mathrm{R}$-squared & 0.704 & 0.704 & 0.738 & 0.721 \\
\hline Adjusted R-squared & 0.408 & 0.408 & 0.469 & 0.439 \\
\hline
\end{tabular}

Robust standard errors in parentheses $(* * * \mathrm{p}<0.01, * * \mathrm{p}<0.05, * \mathrm{p}<0.1)$ 
Table 5 Interaction terms by data sample

\begin{tabular}{|c|c|c|c|c|c|c|c|c|c|c|c|c|c|c|}
\hline \multirow[t]{2}{*}{ Data selections } & & \multirow[t]{2}{*}{$\mathrm{N}$} & \multicolumn{4}{|c|}{$1^{\text {st }} \mathrm{PC}$ from 6 appliances } & \multicolumn{8}{|c|}{ Three appliances } \\
\hline & & & Sex & St. err. & PCA & St. err. & Sex & St. err. & $\begin{array}{l}\text { Gas cooker } \times \\
\text { sex }\end{array}$ & St. err. & $\begin{array}{l}\text { Microwave } \times \\
\text { sex }\end{array}$ & St. err. & $\begin{array}{l}\text { Vacuum } \times \\
\text { sex }\end{array}$ & St. err. \\
\hline All & (1) & 72,960 & $0.952 * * *$ & $(0.029)$ & $0.078 * * *$ & $(0.007)$ & $0.976 * * *$ & $(0.028)$ & $0.281 * * *$ & $(0.025)$ & $0.274 * * *$ & $(0.103)$ & 0.004 & $(0.119)$ \\
\hline Dual-nonworking & (2) & 3,972 & $0.874 * * *$ & $(0.136)$ & $0.101 * * *$ & $(0.036)$ & $0.863 * * *$ & $(0.127)$ & $0.439 * * *$ & $(0.129)$ & 0.108 & $(0.263)$ & -0.492 & $(0.375)$ \\
\hline Dual-working & (3) & 60,506 & $0.881 * * *$ & $(0.030)$ & $0.062 * * *$ & $(0.007)$ & $0.910 * * *$ & $(0.029)$ & $0.204 * * *$ & $(0.024)$ & $0.250 * *$ & $(0.120)$ & 0.172 & $(0.127)$ \\
\hline Dual-wage earner & (4) & 12,120 & $1.001 * * *$ & $(0.060)$ & $0.043 * * *$ & $(0.016)$ & $1.013 * * *$ & $(0.057)$ & $0.145^{* * *}$ & $(0.054)$ & 0.010 & $(0.234)$ & 0.347 & $(0.241)$ \\
\hline Pure dual-wage earner & (5) & 4,642 & $1.149 * * *$ & $(0.112)$ & 0.026 & $(0.031)$ & $1.179 * * *$ & $(0.105)$ & 0.051 & $(0.105)$ & -0.150 & $(0.251)$ & $0.498 *$ & $(0.276)$ \\
\hline Living without a child & (6) & 7,708 & $0.803^{* * *}$ & $(0.077)$ & $0.060 * * *$ & $(0.021)$ & $0.848 * * *$ & $(0.076)$ & $0.143 *$ & $(0.074)$ & $0.526^{*}$ & $(0.302)$ & -0.089 & $(0.245)$ \\
\hline 1 child $^{\mathrm{a}}$ & (7) & 15,366 & $0.978 * * *$ & $(0.061)$ & $0.066 * * *$ & $(0.017)$ & $0.992 * * *$ & $(0.056)$ & $0.236^{* * *}$ & $(0.054)$ & 0.274 & $(0.233)$ & 0.042 & $(0.269)$ \\
\hline 2 children & (8) & 29,734 & $0.918 * * *$ & $(0.044)$ & $0.083 * * *$ & $(0.011)$ & $0.939 * * *$ & $(0.042)$ & $0.306^{* * *}$ & $(0.037)$ & 0.195 & $(0.143)$ & 0.086 & $(0.178)$ \\
\hline 3 children & (9) & 12,916 & $1.025^{* * *}$ & $(0.088)$ & $0.096 * * *$ & $(0.017)$ & $1.079 * * *$ & $(0.090)$ & $0.324 * * *$ & $(0.064)$ & $0.448 *$ & $(0.240)$ & -0.096 & $(0.264)$ \\
\hline 4 children & (10) & 4,664 & $1.094 * * *$ & $(0.129)$ & $0.066^{* *}$ & $(0.030)$ & $1.105 * * *$ & $(0.123)$ & $0.251^{* *}$ & $(0.102)$ & 0.501 & $(0.607)$ & -0.366 & $(0.679)$ \\
\hline$>4$ children & (11) & 2,572 & $1.210 * * *$ & $(0.167)$ & 0.033 & $(0.039)$ & $1.140 * * *$ & $(0.162)$ & $0.363^{* *}$ & $(0.163)$ & -1.069 & $(0.680)$ & -0.229 & $(1.230)$ \\
\hline Husband aged $<26$ & (12) & 576 & $1.033 * * *$ & $(0.368)$ & 0.081 & $(0.065)$ & $1.120 * * *$ & $(0.377)$ & 0.143 & $(0.365)$ & & & & \\
\hline Husband aged 26-35 & (13) & 9,308 & $0.949 * * *$ & $(0.087)$ & $0.040 * *$ & $(0.018)$ & $0.910 * * *$ & $(0.084)$ & $0.273 * * *$ & $(0.069)$ & -0.266 & $(0.341)$ & 0.191 & $(0.362)$ \\
\hline Husband aged 36-45 & (14) & 23,292 & $0.990 * * *$ & $(0.054)$ & $0.062 * * *$ & $(0.013)$ & $1.010 * * *$ & $(0.053)$ & $0.236 * * *$ & $(0.042)$ & 0.109 & $(0.263)$ & 0.126 & $(0.249)$ \\
\hline Husband aged 46-55 & (15) & 21,686 & $0.952 * * *$ & $(0.049)$ & $0.090 * * *$ & $(0.012)$ & $0.994 * * *$ & $(0.047)$ & $0.287 * * *$ & $(0.044)$ & $0.291 * *$ & $(0.144)$ & 0.156 & $(0.170)$ \\
\hline Husband aged 56-65 & (16) & 10,192 & $0.853 * * *$ & $(0.077)$ & $0.105^{* * *}$ & $(0.020)$ & $0.918 * * *$ & $(0.071)$ & $0.314 * * *$ & $(0.066)$ & $0.410 *$ & $(0.238)$ & -0.350 & $(0.283)$ \\
\hline Husband aged $>65$ & (17) & 7,906 & $0.799 * * *$ & $(0.095)$ & $0.072 * * *$ & $(0.022)$ & $0.805 * * *$ & $(0.093)$ & $0.272 * * *$ & $(0.082)$ & $0.437 *$ & $(0.254)$ & -0.017 & $(0.408)$ \\
\hline $1^{\text {st }}$ quartile income & (18) & 18,236 & $0.855^{* * *}$ & $(0.064)$ & 0.017 & $(0.014)$ & $0.849 * * *$ & $(0.063)$ & $0.194 * * *$ & $(0.073)$ & -0.855 & $(1.149)$ & 0.237 & $(0.436)$ \\
\hline $2^{\text {nd }}$ quartile income & (19) & 18,238 & $0.967 * * *$ & $(0.055)$ & $0.033 * *$ & $(0.014)$ & $0.949 * * *$ & $(0.052)$ & $0.224 * * *$ & $(0.047)$ & 0.118 & $(0.425)$ & -0.266 & $(0.378)$ \\
\hline $3^{\text {rd }}$ quartile income & (20) & 18,252 & $1.056^{* * *}$ & $(0.062)$ & $0.055 * * *$ & $(0.016)$ & $1.081 * * *$ & $(0.057)$ & $0.169 * * *$ & $(0.048)$ & $0.511^{*}$ & $(0.265)$ & -0.096 & $(0.307)$ \\
\hline $4^{\text {th }}$ quartile income & (21) & 18,234 & $0.970 * * *$ & $(0.071)$ & $0.096 * * *$ & $(0.019)$ & $1.041 * * *$ & $(0.069)$ & $0.249 * * *$ & $(0.065)$ & $0.198 *$ & $(0.115)$ & -0.010 & $(0.141)$ \\
\hline Household size $<4$ & (22) & 18,408 & $0.917 * * *$ & $(0.054)$ & $0.054 * * *$ & $(0.015)$ & $0.927 * * *$ & $(0.050)$ & $0.197 * * *$ & $(0.049)$ & 0.224 & $(0.222)$ & -0.030 & $(0.228)$ \\
\hline Household size $=4$ & (23) & 24,990 & $0.930 * * *$ & $(0.048)$ & $0.086 * * *$ & $(0.011)$ & $0.971 * * *$ & $(0.046)$ & $0.267 * * *$ & $(0.041)$ & $0.351 * *$ & $(0.150)$ & 0.165 & $(0.196)$ \\
\hline Household size $=5$ & (24) & 15,138 & $0.969 * * *$ & $(0.069)$ & $0.090 * * *$ & $(0.015)$ & $1.004 * * *$ & $(0.071)$ & $0.333 * * *$ & $(0.055)$ & 0.328 & $(0.241)$ & -0.048 & $(0.257)$ \\
\hline Household size $>5$ & (25) & 14,424 & $1.048 * * *$ & $(0.078)$ & $0.072 * * *$ & $(0.016)$ & $1.047 * * *$ & $(0.074)$ & $0.343 * * *$ & $(0.060)$ & 0.161 & $(0.244)$ & -0.209 & $(0.303)$ \\
\hline Dual chore undertaken & $(26)$ & 51,848 & $0.630 * * *$ & $(0.027)$ & $0.067 * * *$ & $(0.007)$ & $0.672 * * *$ & $(0.026)$ & $0.197 * * *$ & $(0.023)$ & $0.299 * * *$ & $(0.106)$ & 0.114 & $(0.121)$ \\
\hline
\end{tabular}

Children are those of the head and coresiding in the household 
Table 6 Mean comparison tests between two samples, with and without gas cooker

\begin{tabular}{|c|c|c|c|c|c|}
\hline \multirow[t]{2}{*}{ Data selections } & \multicolumn{2}{|c|}{ Gas cooker available (A) } & \multicolumn{2}{|c|}{ Without gas cooker (B) } & \multirow{2}{*}{$\begin{array}{l}\text { Difference } \\
(\mathrm{A})-(\mathrm{B})\end{array}$} \\
\hline & Obs. & Mean & Obs. & Mean & \\
\hline \multicolumn{6}{|l|}{ All } \\
\hline Participation- $-\mathrm{H}^{\mathrm{a}}$ & 16,279 & 0.6958 & 20,201 & 0.7563 & $-0.0605^{* * *}$ \\
\hline Participation-W & 16,279 & 0.9599 & 20,201 & 0.9659 & $-0.0060 * * *$ \\
\hline Time gap- $\mathrm{a}^{\mathrm{b}}$ & 16,279 & 1.3831 & 20,201 & 1.0622 & $0.3209 * * *$ \\
\hline Time gap-b & 10,984 & 0.9306 & 14,940 & 0.7382 & $0.1924 * * *$ \\
\hline \multicolumn{6}{|l|}{ Pure dual-wage owners } \\
\hline Participation-H & 1,753 & 0.7467 & 568 & 0.6919 & 0.0548 \\
\hline Participation-W & 1,753 & 0.9738 & 568 & 0.9613 & $0.0125 * *$ \\
\hline Time gap-a & 1,753 & 1.2801 & 568 & 1.2324 & 0.0477 \\
\hline Time gap-b & 1,286 & 0.9393 & 384 & 0.8646 & 0.0747 \\
\hline \multicolumn{6}{|l|}{ Age husband $<26$} \\
\hline Participation-H & 62 & 0.8065 & 226 & 0.8717 & -0.0652 \\
\hline Participation-W & 62 & 0.9839 & 226 & 0.9956 & 0.0117 \\
\hline Time gap-a & 62 & 1.4839 & 226 & 0.9558 & $0.5281 * * *$ \\
\hline Time gap-b & 50 & 1.100 & 196 & 0.6990 & $0.4010 * *$ \\
\hline
\end{tabular}

$* * * \mathrm{p}<0.01, * * \mathrm{p}<0.05, * \mathrm{p}<0.1$

${ }^{\mathrm{a}}$ Participation-H (W) is percentage of husbands (wives) who spent at least one minute on unpaid housework

${ }^{\mathrm{b}}$ Time gap-a (b) is the time difference between a wife and husband using the sample of all (dual chore undertaken) couples 
Appendix Robustness checks by separating each home appliance per estimation and by data sample

\begin{tabular}{|c|c|c|c|c|c|c|c|c|c|c|c|c|c|c|}
\hline \multirow[t]{2}{*}{ Data selections } & & \multirow[t]{2}{*}{$\mathrm{N}$} & \multicolumn{12}{|c|}{ Interaction between sex and } \\
\hline & & & Gas cooker & Std. err. & $\begin{array}{l}\text { Microwave } \\
\text { oven }\end{array}$ & Std. err. & $\begin{array}{l}\text { Vacuum } \\
\text { cleaner }\end{array}$ & Std. err. & Freezer & Std. err. & $\begin{array}{l}\text { Washing } \\
\text { machine }\end{array}$ & Std. err. & $\begin{array}{l}\text { Rice } \\
\text { cooker }\end{array}$ & Std. err. \\
\hline All & (1) & 72,960 & $0.295 * * *$ & $(0.025)$ & $0.399 * * *$ & $(0.097)$ & $0.224 * *$ & $(0.113)$ & $0.244 * * *$ & $(0.028)$ & $0.326 * * *$ & $(0.044)$ & $0.138 * * *$ & $(0.025)$ \\
\hline Dual-nonworking & (2) & 3,972 & $0.434 * * *$ & $(0.127)$ & 0.142 & $(0.249)$ & -0.348 & $(0.353)$ & $0.358 * * *$ & $(0.127)$ & $0.328 * *$ & $(0.152)$ & $0.289 *$ & $(0.151)$ \\
\hline Dual-working & (3) & 60,506 & $0.218^{* * *}$ & $(0.024)$ & $0.383^{* * *}$ & $(0.113)$ & $0.349 * * *$ & $(0.121)$ & $0.181 * * *$ & $(0.027)$ & $0.291 * * *$ & $(0.046)$ & $0.107 * * *$ & $(0.024)$ \\
\hline Dual-wage earner & (4) & 12,120 & $0.158 * * *$ & $(0.054)$ & 0.169 & $(0.205)$ & $0.408^{* *}$ & $(0.201)$ & $0.149 * *$ & $(0.062)$ & $0.161 *$ & $(0.084)$ & 0.063 & $(0.056)$ \\
\hline Pure dual-wage earner & (5) & 4,642 & 0.058 & $(0.104)$ & 0.001 & $(0.222)$ & $0.421 *$ & $(0.230)$ & 0.091 & $(0.099)$ & 0.024 & $(0.106)$ & 0.051 & $(0.123)$ \\
\hline Living without a child & (6) & 7,708 & $0.165^{* *}$ & $(0.073)$ & $0.579 * *$ & $(0.286)$ & 0.125 & $(0.240)$ & $0.203 * *$ & $(0.084)$ & $0.357 * *$ & $(0.175)$ & -0.003 & $(0.077)$ \\
\hline 1 child $^{\mathrm{a}}$ & (7) & 15,366 & $0.254 * * *$ & $(0.054)$ & $0.383 *$ & $(0.219)$ & 0.242 & $(0.259)$ & $0.197 * * *$ & $(0.060)$ & $0.263 * * *$ & $(0.094)$ & $0.094 *$ & $(0.056)$ \\
\hline 2 children & (8) & 29,734 & $0.318 * * *$ & $(0.037)$ & $0.335 * *$ & $(0.135)$ & 0.273 & $(0.170)$ & $0.237 * * *$ & $(0.040)$ & $0.306^{* * *}$ & $(0.057)$ & $0.158 * * *$ & $(0.039)$ \\
\hline 3 children & (9) & 12,916 & $0.341 * * *$ & $(0.064)$ & $0.567 * *$ & $(0.223)$ & 0.213 & $(0.234)$ & $0.358 * * *$ & $(0.072)$ & $0.431 * * *$ & $(0.121)$ & $0.173 * * *$ & $(0.061)$ \\
\hline 4 children & (10) & 4,664 & $0.264 * *$ & $(0.103)$ & 0.539 & $(0.545)$ & 0.039 & $(0.541)$ & 0.100 & $(0.130)$ & $0.442 *$ & $(0.245)$ & $0.192 * *$ & $(0.093)$ \\
\hline More than 4 children & (11) & 2,572 & $0.326^{* *}$ & $(0.162)$ & -0.933 & $(0.580)$ & -1.073 & (1.107) & 0.221 & $(0.188)$ & -0.027 & $(0.362)$ & $0.376^{* * *}$ & $(0.133)$ \\
\hline Husband age $<26$ & (12) & 576 & 0.143 & $(0.365)$ & & & & & 0.474 & $(0.441)$ & 0.482 & $(0.833)$ & 0.411 & $(0.260)$ \\
\hline Husband age $26-35$ & (13) & 9,308 & $0.268 * * *$ & $(0.068)$ & -0.065 & $(0.356)$ & 0.220 & $(0.369)$ & $0.155^{*}$ & $(0.083)$ & 0.044 & $(0.126)$ & $0.153 * *$ & $(0.065)$ \\
\hline Husband age $36-45$ & (14) & 23,292 & $0.243 * * *$ & $(0.042)$ & 0.241 & $(0.233)$ & 0.256 & $(0.212)$ & $0.199 * * *$ & $(0.048)$ & $0.227 * * *$ & $(0.078)$ & $0.156^{* * *}$ & $(0.042)$ \\
\hline Husband age $46-55$ & (15) & 21,686 & $0.308 * * *$ & $(0.044)$ & $0.445^{* * *}$ & $(0.135)$ & $0.377 * *$ & $(0.160)$ & $0.237 * * *$ & $(0.047)$ & $0.385 * * *$ & $(0.073)$ & $0.135^{* * *}$ & $(0.047)$ \\
\hline Husband age $56-65$ & (16) & 10,192 & $0.333 * * *$ & $(0.065)$ & $0.477 * *$ & $(0.228)$ & -0.075 & $(0.267)$ & $0.349 * * *$ & $(0.073)$ & $0.544 * * *$ & $(0.108)$ & $0.116^{*}$ & $(0.070)$ \\
\hline Husband age $>65$ & (17) & 7,906 & $0.302 * * *$ & $(0.081)$ & $0.556 * *$ & $(0.250)$ & 0.274 & $(0.410)$ & $0.252 * * *$ & $(0.091)$ & $0.252 *$ & $(0.146)$ & 0.056 & $(0.083)$ \\
\hline $1^{\text {st }}$ quartile income & (18) & 18,236 & $0.190 * * *$ & $(0.073)$ & -0.711 & (1.147) & 0.217 & $(0.400)$ & 0.023 & $(0.112)$ & -0.166 & $(0.278)$ & 0.051 & $(0.043)$ \\
\hline $2^{\text {nd }}$ quartile income & (19) & 18,238 & $0.224 * * *$ & $(0.047)$ & 0.182 & $(0.418)$ & -0.227 & $(0.389)$ & 0.008 & $(0.062)$ & 0.061 & $(0.190)$ & 0.024 & $(0.045)$ \\
\hline $3^{\text {rd }}$ quartile income & (20) & 18,252 & $0.174 * * *$ & $(0.048)$ & $0.556^{* *}$ & $(0.270)$ & 0.008 & $(0.300)$ & $0.091^{*}$ & $(0.051)$ & $0.203^{* *}$ & $(0.089)$ & 0.040 & $(0.061)$ \\
\hline $4^{\text {th }}$ quartile income & (21) & 18,234 & $0.267 * * *$ & $(0.064)$ & $0.233 * *$ & $(0.107)$ & 0.112 & $(0.132)$ & $0.269 * * *$ & $(0.055)$ & $0.224 * * *$ & $(0.058)$ & 0.050 & $(0.084)$ \\
\hline Household size $<4$ & (22) & 18,408 & $0.208 * * *$ & $(0.049)$ & 0.304 & $(0.209)$ & 0.124 & $(0.216)$ & $0.183^{* * *}$ & $(0.056)$ & $0.240 * *$ & $(0.096)$ & 0.033 & $(0.050)$ \\
\hline Household size $=4$ & (23) & 24,990 & $0.288 * * *$ & $(0.040)$ & $0.494 * * *$ & $(0.141)$ & $0.393 * *$ & $(0.188)$ & $0.242 * * *$ & $(0.044)$ & $0.323 * * *$ & $(0.063)$ & $0.154 * * *$ & $(0.044)$ \\
\hline Household size $=5$ & (24) & 15,138 & $0.345^{* * *}$ & $(0.054)$ & $0.457 * *$ & $(0.228)$ & 0.206 & $(0.246)$ & $0.291 * * *$ & $(0.060)$ & $0.391 * * *$ & $(0.099)$ & $0.167 * * *$ & $(0.052)$ \\
\hline Household size $>5$ & (25) & 14,424 & $0.347 * * *$ & $(0.060)$ & 0.272 & $(0.224)$ & 0.034 & $(0.275)$ & $0.251 * * *$ & $(0.068)$ & $0.340 * * *$ & $(0.112)$ & $0.205^{* * *}$ & $(0.056)$ \\
\hline Dual chore undertaken & (26) & 51,848 & $0.214 * * *$ & $(0.023)$ & $0.413^{* * * *}$ & $(0.100)$ & $0.306^{* * * *}$ & $(0.116)$ & $0.205^{* * *}$ & $(0.027)$ & $0.299 * * *$ & $(0.044)$ & $0.142 * * *$ & $(0.022)$ \\
\hline
\end{tabular}

${ }^{\mathrm{a}}$ Children are those of the head and are coresiding in the household 